\title{
Hubungan Pengetahuan Mahasiswi dan Dukungan Orang Tua Terhadap Minat Mahasiswi DIII Kebidanan Menjadi Relawan dalam Membantu Indonesia Menghadapi Covid-19
}

\author{
Rosa Susanti ${ }^{1,}$ Hainun Nisa ${ }^{2}$ \\ Universitas Mohammad Husni Thamrin ${ }^{1}$ \\ STIKes Medistra ${ }^{2}$ \\ rosasusanti@thamrin.ic.id
}

\begin{abstract}
Abstrak
Kemdikbud menghimbau para mahasiswa fakultas kesehatan tingkat akhir untuk menjadi relawan dan berperan aktif dalam pecegahan penyebaran covid-19. Menjadi relawan merupakan suatu kegiatan kemanusian yang sangat nyata. Banyak orang berminat menjadi relawan, baik pada kalangan remaja ataupun kalangan orang dewasa. Penelitian ini menggunakan metode kuantitatif dengan pendekatan deskriptif, penelitian ini bertujuan untuk memperoleh informasi hubungan Pengetahuan Mahasiswi Dan Dukungan Orang Tua Terhadap Minat Mahasiswa Menjadi Relawan Dalam Membantu Indonesia Menghadapi Covid-19 secara studi cross sectional, dengan respnden mahasiswi Tingkat Akhir DIII kebidanan Fakultas Kesehatan Universits MH. Thamrin dan STIKes Medistra. Hasil penelitian diketahui bahwa terdapat hubungan dukungan orang tua terhadap Minat Mahasiswa Menjadi Relawan Dalam Membantu Indonesia Menghadapi Covid-19 dengan $\mathrm{p}=0.000$.
\end{abstract}

kata kunci: Pengetahuan, Relawan, Mahasiswi, Dukungan, Minat

\begin{abstract}
Kemdikbud urges final level health faculty students to volunteer and play an active role in preventing the spread of covid-19. Volunteering is a very real humanitarian activity, many people interested in volunteering, both among teenagers and adults. This research method is a quantitative method with a descriptive approach because this study aims to obtain information on the korelasi of Knowledge and Parental Support on Student Interest in Becoming Volunteers in Helping Indonesia to Face Covid-19 in a cross-sectional study, with the respondents of midwifery DIII final level students of the Faculty of Health, MH Universits MH. Thamrin and STIKes Medistra The results of the study show that there is a significant relationship between support from parents and student interest in becoming volunteers in helping Indonesia to face Covid-19 with $p$ $=0.000$
\end{abstract}

keywords: Knowledge, volunteer, student, support, interest

\section{PENDAHULUAN}

WHO menyatakan bahwa Coronavirus19 merupakan pandemi dunia (WHO,2020). Coronavirus dapat menular melalui hewan dan manusia. Penyakit dan Virus ini diketahui sejak bulan Desember 2019 berawal di kota Wuhan, Cina. Jumlah kasus penyakit pada tanggal 21 Maret 2020 telah menyebar di 166 Negara dengan jumlah jiwa sebanyak 275,469 jiwa. Presiden Republik Indonesia Pada tanggal 17 Maret 2020 menyatakan bahwa status penyakit ini menjadi tahap Tanggap Darurat. (Gugus Tugas Percepatan Penanganan COVID-19, 2020).

Keputusan Presiden No. 7 Tahun 2020 tentang Gugus Tugas Percepatan Penanganan Corona yang dikeluarkan oleh presiden RI memutuskan bahwa Kepala Badan Nasional Penanggulangan Bencana (BNPB) sebagai ketua dalam percepatan penanganan kasus ini.

http://ejournal.urindo.ac.id/index.php/kesehatan 
Tujuan Gugus tugas percepatan penanganan corona sebagai berikut (1) ketahanan nasional di bidang kesehatan meningkat(2) adanya sinergi antar kementria atau lembaga serta pemerintah daerah dalam mempercepat penanganan coronavirus -19 (3) kewaspadaan perkembangan eskalasi penyebaran coronavirus-19 dapat meningkat (4) peningkatan sinergi pengabilan kebijakan nasional dapat dan (5) meningkatkan kesiapan serta kemampuan untuk mencegah, mendeteksi dan merespon terhadap Covid-19. (Gugus Tugas Percepatan Penanganan COVID-19, 2020)

Kemendikbud menghimbau para mahasiswa fakultas kesehatan tingkat akhir untuk menjadi relawan dan berperan aktif dalam pecegahan penyebaran covid-19 (Covid-19). Fokus para relawan melakukan kegiatan pencegahan edukasi, serta pengendalian pandemic Covid-19. Makarim menyampaikan bahwa keterlibatan para relawan merupakan upaya gotong royong serta gerakan masyarakat secara sukarela untuk mencegah penyebaran Covid-19. "Kita dalam situasi yang belum pernah dialami sebelumnya dan membutuhkan upaya sekuat tenaga untuk menangani situasi ini. Kami paham betul bahwa risiko terkait hal ini cukup besar, namun upaya ini tidaklah akan berhasil tanpa dukungan seluruh masyarakat, terutama bagi generasi muda yang memiliki talenta-talenta yang tepat. Tidak ada paksaan. Ini adalah gerakan sukarela. Negara membutuhkan pahlawanpahlawan medis yang berjuang bersama demi masyarakat," Mendikbud di Jakarta, pada hari Jumat (20/3/2020). Mendikbud menegaskan, bahwa para relawan tidak langsung menangani pasien, namun membantu program-program komunikasi, informasi, dan edukasi kepada masyarakat, melayani call center, serta menyiapkan diri sebagai tenaga bantuan dalam kondisi darurat sesuai kompetensi dan kewenangannya. "Kepada mahasiswa yang berminat untuk ikut serta dalam kegiatan ini akan diberikan pelatihan dan pendampingan, disiapkan alat perlindungan diri (APD) yang sesuai standar
Organisasi Kesehatan Dunia (WHO), insentif dari Kemendikbud, dan sertifikat pengabdian kepada masyarakat yang dapat disesuaikan oleh universitas masing-masing untuk menjadi bagian dari penilaian kinerja dalam program Co-As atau sebagai satuan kredit semester,

"Nadiem menerangkan bahwa. Kemendikbud telah menyampaikan kepada Rektor/Direktur Politeknik Kesehatan untuk mendorong Dekan Fakultas Kedokteran/Keperawatan/IImu Kesehatan Masyarakat untuk mensosialisasikan inisiatif ini kepada seluruh mahasiswa tingkat akhir/Co-Asssistant (Co-As) supaya dapat bergotong royong menjadi relawan kemanusiaan dalam mendukung pencegahan meluasnya covid-19.

Proses koordinasi dengan berbagai pimpinan perguruan tinggi sampai saat ini terus dilakukan.

Plt. Dirjen Dikti Nizam, menyampaikan bahwa inisiatif yang telah digagas ini berharap dapat meningkatkan kompetensi dan membentuk jiwa kemanusiaan yang kuat bagi para mahasiswa, khususnya bagi para calon dokter dan tenaga medis. Ditjen Dikti Kemendikbud bekerjasama dengan Ikatan Senat Mahasiswa Kedokteran Indonesia (ISMKI) dan Asosiasi Institusi Pendidikan Kedokteran Indonesia (AIPKI) untuk menggerakkan para mahasiswa kedokteran yang ingin terlibat dan mendukung upaya pemerintah menjadi relawan dalam memerangi Covid-19," ungkap Nizam. Ditjen Dikti Kemendikbud akan terus berkoordinasi dengan para pimpinan perguruan tinggi terkait detail teknis pelaksanaan pendaftaran, pelatihan, serta berbagai dukungan yang dibutuhkan untuk menjalankan inisiatif ini. Kemendikbud Sampai saat ini, telah mengkoordinasikan dan dan mengkonsolidasikan kepada 26 Fakultas Kedokteran dan Rumah Sakit Pendidikan sebagai sub-center untuk screening dan penanganan pasien Covid-19. (ttps://www.kemdikbud.go.id)

Menjadi relawan merupakan suatu kegiatan kemanusian yang sangat nyata. 
banyak orang berminat menjadi relawan, baik pada kalangan remaja ataupun kalangan orang dewasa

Adapaun Tujuan dari penelitian ini untuk mengetahui Pengaruh Pengetahuan Dan Dukungan Orang Tua Terhadap Minat Mahasiswi DIII Kebidanan Menjadi Relawan Dalam Membantu Indonesia Menghadapi Covid-19

\section{Metode}

Metode pada penelitian menggunakan metode kuantitatif dengan pendekatan deskriptif. Responden penelitian ini adalah Mahasiswa DIII Kebidanan Universitas MH. Thamrin dan STIKes Medistra Indonesia Tingkat III. Penelitian ini dilakukan Universitas $\mathrm{MH}$. Thamrin dan STIKes Medistra. Waktu yang diperlukan untuk penelitian selama 1 (satu) bulan efektif dari bulan April sampai dengan bulan Mei 2020. Tahap penelitian sebagai berikut: tahap (i) menyebarankan Link Google Form, tahap (2) melakukan pengolahan data dan (3) melakukan analisis data. pada penelitian ini menggunakan data primer, teknik analisis yang digunakan yaitu analisis univariat dan bivariat (Uji Chi Square).

\section{HASIL DAN PEMBAHASAN}

Tabel 1

Distribusi Frekuensi Pengetahuan Mahasiswi Dalam Membantu Indonesia Menghadapi COVID-19 Berdasarkan Pengetahuan Tahun 2020

\begin{tabular}{ccr} 
Pengetahuan & Frekuensi & Presen \\
\hline Tinggi & 27 & 37 \\
Rendah & 46 & 63
\end{tabular}

Tabel 2 diketahui bahwa responden dengan pengetahuan tinggi sebanyak $54.8 \%$ dan $45.2 \%$ pengetahuan rendah.

Tabel 2

Distribusi Frekuensi Dukungan Orang Tua Dalam Membantu Indonesia Menghadapi COVID-19 Berdasarkan Dukungan Orang Tua Tahun 2020

Dukungan $\quad$ Frekuensi $\quad$ Presen

\begin{tabular}{ccc}
\hline Orang Tua & & tase \\
Mendukung & 36 & 49.3 \\
Tidak & 37 & 50.7 \\
Mendukung & & \\
\hline
\end{tabular}

Tabel 3 diketahui bahwa responden dengan dukungan orang tua sebanyak $54.8 \%$ dan $45.2 \%$ orang tua tidak mendukung.

Tabel 3

Distribusi Frekuensi Minat Mahasiswa Menjadi Relawan Dalam Membantu Indonesia Menghadapi COVID-19 Tahun 2020

\begin{tabular}{ccc}
\hline Minat & Frekuensi & Presentase \\
\hline Minat & 40 & 54.8 \\
Tidak Minat & 33 & 45.2 \\
\hline
\end{tabular}

Tabel 1 diketahui bahwa responden yang berminat menjadi Relawan Dalam Membantu Indonesia Menghadapi COVID-19 yaitu $54.8 \%$ dan $45.2 \%$ tidak berminat menjadi Relawan.

Tabel 4

Hasil Analisis Hubungan Pengetahuan Mahasiswi Dengan Minat Mahasiswi Menjadi Relawan Dalam Membantu Indonesia Menghadapi COVID-19 Tahun 2020

\begin{tabular}{|c|c|c|c|c|c|c|}
\hline \multirow{4}{*}{$\begin{array}{c}\text { Pengetah } \\
\text { uan }\end{array}$} & \multicolumn{4}{|c|}{ Minat } & \multirow{4}{*}{$\begin{array}{c}\text { OR } \\
(95 \% \\
\text { Cl) }\end{array}$} & \multirow{4}{*}{$\begin{array}{c}\mathrm{P} \\
\text { Valu } \\
\mathrm{e}\end{array}$} \\
\hline & \multirow{2}{*}{\multicolumn{2}{|c|}{ Minat }} & \multirow{2}{*}{\multicolumn{2}{|c|}{$\begin{array}{l}\text { Tidak } \\
\text { Minat }\end{array}$}} & & \\
\hline & & & & & & \\
\hline & $\mathrm{n}$ & $\%$ & $\mathrm{n}$ & $\%$ & & \\
\hline Tinggi & 17 & 63 & 10 & 37 & 0.64 & 0.40 \\
\hline Rendah & 23 & 50 & 23 & 50 & $3-$ & 6 \\
\hline \multirow[t]{2}{*}{ tasemlah } & 40 & 54.8 & 33 & 45.2 & 4.49 & \\
\hline & & & & & 2 & \\
\hline
\end{tabular}

Tabel 4 dapat diketahui bahwa analisis hubungan pengetahuan dan minat mahasiswa menjadi relawan dalam membantu Indonesia Menghadapi COVID 19 diketahui bahwa Mahasiswi dengan pengetahuan tinggi berminat menjadi relawan sebanyak $63 \%$, sedangkan dengan pengetahuan rendah yang berminat menjadi relawan sebanyak $50 \%$.

Uji statistik hubungan pengetahuan dengan minat mahasiswa menjadi relawan dalam membantu Indonesia Menghadapi 
COVID -19 didapatkan nilai $p$ value 0,406 , yang berarti tidak terdapat hubungan yang signifikan pengetahuan dan minat mahasiswa menjadi relawan dalam membantu Indonesia Menghadapi COVID 19.

\section{Tabel 5}

Hasil Analisis Hubungan Dukungan Orang Tua Dengan Minat Mahasiswa Menjadi Relawan Dalam Membantu Indonesia Menghadapi COVID-19 Tahun 2020

\begin{tabular}{|c|c|c|c|c|c|c|}
\hline \multirow{4}{*}{$\begin{array}{l}\text { Dukungan } \\
\text { Orang Tua }\end{array}$} & \multicolumn{4}{|c|}{ Minat } & \multirow{4}{*}{$\begin{array}{c}\text { OR } \\
(95 \% \\
\text { Cl) }\end{array}$} & \multirow{4}{*}{$\begin{array}{c}\mathrm{P} \\
\text { Valu } \\
\mathrm{e}\end{array}$} \\
\hline & \multirow{2}{*}{\multicolumn{2}{|c|}{ Minat }} & \multirow{2}{*}{\multicolumn{2}{|c|}{$\begin{array}{l}\text { Tidak } \\
\text { Minat }\end{array}$}} & & \\
\hline & & & & & & \\
\hline & $\mathrm{N}$ & $\%$ & $\mathrm{n}$ & $\%$ & & \\
\hline Mendukung & 29 & 80.6 & 7 & 19.4 & 3.30 & 0.00 \\
\hline Tidak & 11 & 29.4 & 26 & 70.3 & 7- & 0 \\
\hline Mendukung & & & & & 29.9 & \\
\hline Jumlah & 40 & 54.8 & 33 & 45.2 & 93 & \\
\hline
\end{tabular}

Dari tabel 5 dapat diketahui bahwa analisis hubungan dukungan orang tua dan minat mahasiswa menjadi relawan dalam membantu Indonesia Menghadapi COVID 19 menunjukkan bahwa Mahasiswi yang mendapat dukungan orang tua yang berminat menjadi relawan sebanyak $80.6 \%$, lebih besar dari tidak mendapat dukungan yang berminat menjadi relawan sebanyak $29.4 \%$.

Hasil uji statistik hubungan
Dukungan Orang tua-dengan minat
mahasiswa menjadi relawan dalam membantu Indonesia Menghadapi COVID 19 didapatkan nilai $p$ value 0,000 , yang menunjukan bahwa terdapat hubungan dukungan orang tua dengan minat mahasiswa menjadi relawan dalam membantu Indonesia Menghadapi COVID 19.

Gambaran Minat Mahasiswa Menjadi Relawan Dalam Membantu Indonesia Menghadapi COVID-19 Tahun 2020

Minat merupakan suatu kegiatan yang dilakukan oleh siswa secara tetap dalam melakukan proses belajar. Sesuia dengan pendapat Slameto bahwa minat merupakan kecenderungan untuk tetap memperhatikan dan mengenang beberapa kegiatan (Slameto, 2010).

Guru harus berusaha membangkitkan minat siswa untuk menguasahai pengetahuan yang terkandung dalam bidang studinya dengan cara kurang lebih sama dengan kiat membangun sikap yang positif. Perasaan senang akan menimbulkan minat yang diperkuat oleh sikap yang positif, namun sebaliknya perasaan yang tidak senang akan menghambat dalam belajar oleh karena tidak akan melahirkan sikap yang positif dan juga tidak menunjang minat dalam belajar.

Minat berpengaruh terhadap diri seseorang, dengan adanya minat maka seseorang akan melakukan sesuatu yang kiranya menghasilkan sesuatu bagi dirinya. Minat merupakan suatu rasa ketertarikan pada suatu hal/aktivitas, mengenang dan memperhatikan kegiatan tanpa adanya yang menyuruh (Azwar, 2013). Seorang yang memiliki minat pada suatu objek, maka dia akan tertarik terhadap suatu objek tersebut (Riwidikdo, 2012).

Berdasarkan hasil penelitian diketahui bahwa $54.8 \%$ (40) responden yang berminat menjadi relawan dan sebanyak $45.2 \%$ (33) responden yang tidak berminat menjadi relawan. Berdasarkan pengetahuan diketahui bahwa sebanyak 37\% (27) dengan pengetahuan tinggi dan sebanyak $63 \%$ (46) dengan pengetahuan rendah. Berdasarkan Dukungan orang tua diketahuai sebanyak $49.3 \%$ (36) responden yang mendapat dukungan dari orang tua dan sebanyak $50.7 \%$ (37) tidak mendapat dukungan dari orang tua

\section{Hubungan Pengetahuan Dengan Minat Mahasiswi Menjadi Relawan Dalam Membantu Indonesia Menghadapi COVID- 19 Tahun 2020}

Pengetahuan merupakan hasil tahu dari manusia, sekedar menjawab pertanyaan "what", Pengetahuan hanya bisa menjawab pertanyaan apa sesuatu itu (Notoatmodjo, 2010). Mubarak (2011) menyatakan bahwa tingkat pendidikan 
rendah akan menghambat perkembangan sikap terhadap penerimaan informasi dan nilai-nilai yang baru diperkenalkan.

Hasil penelitian didapat bahwa sebanyak 63\% (17) dengan pengetahuan tinggi berminat menjadi relawan dan sebanyak $50 \%$ (23) responden dengan pengetahuan rendah yang berminat menjadi relawan dalam membantu Indonesia menghadapi COVID-19.

Uji statistik antara hubungan pengetahuan dengan Minat Mahasiswa Menjadi Relawan Dalam Membantu Indonesia Menghadapi COVID-19 diperoleh nilai $p$ value $=0.406$, menyatakan bahwa tidak ada hubungan antara pengetahuan dengan Minat Mahasiswa Menjadi Relawan Dalam Membantu Indonesia Menghadapi COVID-19. Penelitian ini sejalan dengan penelitian melinda (2016) menunjukkan bahwa tidak terdapat hubungan yang signifikan antara pengetahuan dengan minat

Hal ini tidak sejalan dengan hasil penelitian penelitian Rani Kusumoningtyas dkk (2016) yang menyatakan bahwa semakin baik pengetahuan ibu tentang imunisasi anjuran maka akan meningkatkan minat ibu untuk melakukan imunisasi anjuran. Hal ini mungkin dikarenakan COVID-19 merupakan penyakit baru dan sampai saat ini para peneliti masih mempelajari cara penularannya. diduga penyebaran utama penyakit ini melalui droplet saluran pernapasan dan kontak dekat dengan penderita. Droplet dapat menyebar melalui udara sampai jarak 1 meter dan sampai saat ini belum ditemukan vaksin. (point ini tidak membahas pengetahuan dan minat)

\section{Hubungan Dukungan orang tua Dengan Minat Mahasiswa Menjadi Relawan Dalam Membantu Indonesia Menghadapi COVID- 19 Tahun 2020}

Orang tua merupakan bagian dari lingkungan keluarga yang memiliki pengaruh besar terhadap pilihan yang diambil oleh siswa sehingga dukungan orang tua sangat diperlukan (Minanti, 2016)

Tempat yang pertama kali dikenal oleh individu adalah keluarga. Dalam bersosialisasi di masyarakat peran Keluarga cukup penting. Menurut Cobb (dalam Sarafino, 2006), dukungan orang tua merupakan bagian dari dukungan sosial, sehingga diartikan bahwa keluarga merupakan bagian dari suatu perhatian, kenyamanan, penghargaan, ataupun bantuan yang dirasakan oleh individu dari orang-orang atau kelompok lain.

Francis dan Sariadarma (dalam Ambari, 2010) menyatakan bahwa dukungan keluarga merupakan sebuah bantuan yang diterima oleh seseorang yang bertujuan untuk menjalankan fungsi-fungsi yang terdapat di dalam sebuah keluarga. Ambari (2010) menyatakan bahwa dukungan keluarga, dan dukungan orang tua, dapat mnjadi sebuah kekuatan dalam suatu keluarga, serta memperbesar penghargaan terhadap diri sendiri dan memiliki strategi untuk menghadapi tantangan kehidupan sehari-hari. Begitu juga menurut Sarafino (2006) yang menyatakan bahwa dukungan sosial orang tua mengacu pada memberikan kenyamanan kepada orang lain yang merawatnya atau menghargainya.

Mengambil keputusan menjadi seorang relawan tidaklah mudah untuk menjadi seorang relawan bukanlah pekerjaan yang rutin karena tidak terjadi setiap waktu dan bersifat insidental. Banyak faktor yang mempengaruhi seseorang untuk menjadi relawan. Salah satu faktor yang mempengaruhi seseorang menjadi relawan adalah sikap generativity merupakan sebuah sikap yang berfokus kepada hubungannya dengan keturunan, misalnya seseorang menjadi relawan karena sebelumnya orangtuanya seorang relawan. Karateristik sikap generativity peduli terhadap sesama, saling mengayomi, hangat serta sedikit mengatur.

Hasil penelitian ini menunjukan bahwa sebanyak $80.6 \%$ (29) responden yang berminat menjadi relawan serta mendapat dukungan orang tua dan sebanyak $29.4 \%$ 
(11) responden yang tidak mendapat dukungan orang tua namun berminat menjadi relawan.

Uji statistik antara dukungan orang tua dengan Minat Mahasiswi Menjadi Relawan Dalam Membantu Indonesia Menghadapi COVID-19 didapatkan nilai $p$ value $=0.000$, disimpulkan bahwai terdapat hubungan yang signifikan antara dukungan orang tua dengan Minat Mahasiswa Menjadi Relawan Dalam Membantu Indonesia Menghadapi COVID-19 dengan OR 3.30729.993 artinya mahasiswi mendapat dukungan dari orang tua untuk menjadi relawan berpeluang 3-29 kali berminat menjadi relawan Menjadi Relawan Dalam Membantu Indonesia Menghadapi COVID19.

Hasi penelitian Nurrohmatulloh (2016) menyatakan bahwa orientasi masa depan dan dukungan orang tua dengan minat siswa-siswi SMKN 1 Samarinda kelas XII terdapat hubungan yang signifikan untuk melanjutkan studi ke perguruan tinggi sejalan dengan penelitian ini

Penelitian ini juga sejalan dengan hasil penelitian Melianawati (2015), yang berjudul hubungan dukungan sosial orangtua dengan minat melanjutkan pendidikan ke perguruan tinggi pada remaja di Kecamatan Keluang Musi Banyuasin, penelitian tersebut menyatakan dukungan sosial orangtua dengan minat remaja di Kecamatan Keluang Musi Banyuasin terdapat hubungan yang signifikan untuk melanjutkan pendidikan dengan nilaikoefisien korelasi sebesar 0.329 Begitu juga penelitian Yesika Mayang (2018) yang menyatakan bahwa Dukungan Orangtua Dan Motivasi Belajar dengan Minat pelajar SMA Negeri terdapat hubungan yang signifikan untuk Melanjutkan Studi Ke Perguruan Tinggi

\section{Kesimpulan}

Penelitian ini diketahui bahwa $54.8 \%$ (40) yang berminat menjadi relawan dan sebanyak $45.2 \%$ (33) responden yang tidak berminat menjadi relawan. Berdasarkan pengetahuan diketahui bahwa sebanyak $37 \%$ (27) dengan pengetahuan tinggi dan sebanyak 63\% (46) responden dengan pengetahuan rendah. Berdasarkan Dukungan orang tua diketahuai sebanyak $49.3 \%$ (36) responden yang mendapat dukungan dari orang tua dan sebanyak $50.7 \%$ (37) tidak mendapat dukungan orang tua dan berdasarkan uji statistik diketahui bahwa terdapat hubungan signifikan antara dukungan orang tua dengan minat mahasiswi Menjadi Relawan Dalam Membantu Indonesia Menghadapi COVID-19 dengan nilai $\mathrm{p}$ value $=0.000$.

\section{Daftar Pustaka}

1. Alsa, A. A. N. d. S. T., 2006. Hubungan antara dukungan sosial orang tua dengan kepercayaan diri remaja panyandang cacat fisik pada SLBD YPAC Semarang, Issue jurnal fakultas psikologi Universitas Islam Sultan Agung.

2. Ambari, P. K. M., 2010. Hubungan Antara Dukungan Keluarga Dengan Keberfungsian Sosial Pada Pasien Skizofrenia Pasca Perawatan di Rumah Sakit.

3. Anon., $2020 . \quad$ [Online] Available at: https://id.wikipedia.org/wiki/Pandemi koronavirus di indonesia [Accessed 1 june 2020].

4. Anon., 2020.2 [Online] Available at: https://www.kemdikbud.go.id/main/bl og/2020/03/kemendikbudmengundang-mahasiswa-tingkat-akhirbidang-kesehatan-jadi-relawan-cegahsebatan-covid19

[Accessed 1 june 2020].

5. Anon., 2020. [Online] Available at: 
https://corona.jakarta.go.id/id

[Accessed 1 June 2020].

6. Anon., 2020. pedoman penanganan ceoat medis kesehatan masyarakat COVID-19. s.I.:s.n.

7. Awaludin Baiti, A., 2014. Pengaruh Pengalaman Praktik, Prestasi Belajar Dasar Kejuruan Dan Dukungan Orang Tua Terhadap Kesiapan Kerja Siswa SMK. Jurnal Pendidikan Vokasi, 4(2).

8. Azwar, S., 2013. Sikap Manusia Teori dan Pengukurannya. Yogyakarta: Pustaka Belajar.

9. Kusumoningtyas, R. d., 2016. Hubungan Pengetahuan Ibu Tentang Imunisasi Anjuran dengan Minat Melakukan Imunisasi Anjuran Pada Balita di Politeknik Imunisasi Rumah Sakit Panti Waluya Malang. Nursing Malang, I(2).

10. Mayang, Y., 2018. Dukungan Orang Tua dan Motivasi Belajar dengan Minat Melanjutkan Studi ke Perguruan Tinggi di SMA Negeri PSIKOBORNEO. VI(3).

11. Melianawati, 2015. Hubungan Antara Dukungan Sosial orang tua dengan minat melanjutkan pendidikan perguruan tinggi pada remaja di kecamatan keluang musi Banyuasin. psikologi universitas binadarma palembang, I(1), pp. 1-11.

12.Melinda, d., 2016. faktor-faktor yang berhubungan dengan dengan minat masyarakat dalam keikutsertaan BPJS Mandiri di Kecamatan Bener kabupaten purworejo. kesehatan masyarakat, IV(4).
13.Minati, M., 2016. hubungan dukungan orang tua dengan minat siswa mengikuti ekstrakurikuler karate di SMP Negeri 2 Taman. Pendidikan olahraga dan kesehatan, IV(2).

14.Mubarak, W. I., 2011. Promosi Kesehatan untuk kebidanan. Jakarta: Salemba Medika.

15.Notoatmodjo, s., 2010 promosi kesehatan dan ilmu perilaku. Jakarta: Rineka cipta.

16.Nurrohmatullah, A. M., 2016. hubungan orientasi masa depan dan dukungan orang tua dengan minat melanjutkan studi ke perguruan tinggi (Siswi-siswi SMK Negeri 1 Samarinda Kelas XII. Jurnal Psikologi, IV(4).

17.Riwidikdo, H., 2012. statistik kesehatan. Yogyakarta: Mitra cendikia Press.

18.Safarini, E. P., 2006. Health psychology: biopsychosocial interakctions. USA: Jhon Wiley and Sons.

19.Sarafino, E. P. T. W. S., 1998. Health psychology: biopsychososial interactions. new york: wiley and sons inc.

20.slameto, 2010. belajar dan faktor faktor yang mempengaruhinya. Jakarta: Rhineka Cipta.

21.Syah, M., 2003. Psikologi pendidikan dengan pendekatan baru. Bandung: Remaja Rosdakarya. 